\title{
Code Switching in the Instructions of English Language Education Study Program Lecturers
}

\author{
Thomas Wahyu Prabowo Mukti and Retno Muljani \\ Sanata Dharma University \\ thomaswpm@gmail.com and retno_muljani@yahoo.com
}

\begin{abstract}
Language is an essential mean of communication in teaching and learning activities. Specifically, in the English Language Education Study Program (ELESP) that employs English as the main instructional language for teaching and learning activities. Considering that English was not students' first language, some lecturers employed code switching to help third-semester students in learning English. With regard to this phenomenon, this study addressed two research questions. First, what the types of code switching ELESP lecturers employ in their instructional languages are and second, what the reasons for ELESP lecturers to employ code switching in their instructional languages are. This study belonged to a basic interpretative study. It employed interview guidelines to understand the experiences of the lecturers who employed code switching. The results of this study showed that the lecturers employed both situational and metaphorical code switching. In addition, the writer found that the participants of the study code-switched for the reasons which can be classified into topic, addressee, emphasis, persuasion, solidarity, affection, nature of the subject and strategy. The results of the study also revealed that the use of code switching in lecturers' instructional languages was mainly for the students' understanding.
\end{abstract}

Keywords: code switching, ELESP, lecturers

\section{Introduction}

Language is important in people's lives. Radford, Atkinson, Britain, Clahsen, and Spencer (1999) note that language becomes a tool that bridges person to person or group of people in their society. Language plays a vital role in the socio-economic, political and cultural lives of the people (Adegbite \& Akindele, 1999). Specifically, language is an essential mean of communication in teaching and learning activities. Teachers or lecturers employ languages for explaining and giving directions and/or instructions to students. The language becomes media for students to communicate with teachers or lecturers and their friends. By using clear and proper languages, teachers or lecturers will be able to give accurate instructions to students and they will be able to facilitate students in understanding materials. Thus, 
languages are important in teaching and learning processes.

Functioning as facilitators, teachers or lecturers should master English in order to conduct instructional activities to facilitate the students in classes (Harmer, 2007). The lecturers shall employ English as the main instructional language. However, English is not the mother language of the ELESP students and lecturers. The writer observed that code switching was quite often occurred in the second year students' classes. Both lecturers and students switched English to Indonesian language and other local languages during the activities in the class. The phenomenon of switching languages is found in multilanguage society and the phenomenon belongs to code switching. Code switching happens when speakers shift from one language to another whether it is only one word, utterance and even one sentence (Holmes, 1992). Thus, the ELESP belongs to multilanguage society since the ELESP students are from many places in Indonesia that have their own local languages.

Considering the phenomenon of the use of code switching in the ELESP lecturers' instructional languages, the writer proposes to study types of code switching used by lecturers in their instructional languages and analyze their reasons to switch one language to another language. The use of code switching as the instructional languages by lecturers for teaching the third semester students is chosen since the third semester students should have mastered English well. However, some lecturers still employ code switching for different reasons.

\section{Review of Related Literature}

People have their own codes to communicate with others. Holmes (1992) says that code switching happens when speakers shift from one language to another whether it is only one word, utterance, and even one sentence. The switches can intrasententially occur within a single sentence, inter-sententially between sentences or emblematically in a tag or exclamation of a sentence (Hoffman, 1991).

\section{Types of Code Switching}

Types of code switching vary from a linguist to another. Thus, this study employed types of code switching proposed by Blom and Gumperz (1972) and Wardhaugh (2006).

\section{Situational Code Switching}

Situational code switching occurs when situations, particularly participants, settings and activity types change speakers' language choices (Blom \& Gumperz, 1972). Situational code switching occurs when the languages used change according to the social situations in which the conversant find themselves; they speak one language in one situation and another in a different one. No topic change is involved (Wardhaugh, 2006). The situational code switching can also be used to change the situation (Blom \& Gumperz, 1972). 


\section{Metaphorical Code Switching} Blom and Gumperz (1972) state that metaphorical code switching is the language switch related to particular kinds of topics or subject matter rather than to change the social situation. Similarly, Wardhaugh (2006) states that the metaphorical code switching happens in a situation when a change of topic in the conversation requires a change in the languages used. Some topics may be discussed in either code, but the choice of code adds a distinct flavor to what is said about the topic.

\section{Reasons of Code Switching}

Bilingual people switch their languages for a number of reasons. This study employed reasons of code switching stated in Hoffman (1991), Holmes (1992) and Wardhaugh's (2006) studies to analyze reasons for participants to code-switch. Based on the compilation of Hoffman, Holmes, and Wardhaugh, there are six reasons for people to code switch. They are topic, addresee, emphasis, persuasion, solidarity, and affection. Those factors cannot be separated from each other and they, sometimes, occur on the same events.

\section{Topic}

Holmes (1992) states that people may switch-code within a speech event to discuss a particular topic.
Holmes adds that people find it is easier to discuss particular topics in one code rather than another. Additionally, talking about a particular topic can cause a switch, either because of lack of facility in the relevant register or because certain items trigger off various connotations which are linked to experiences in a particular language (Hoffman, 1991, p. 115).

\section{Addressee}

A code switch may be related to a particular addressee (Holmes, 1992). It means people code-switch according to addressees they are talking. This code switching depends on addressees' background, relation to the speaker, and language mastery (Holmes, 1992).

\section{Emphasis}

Hoffman (1991) states that being empathic about something can trigger code switching when a subject is quoting somebody else to emphasize about something. This switch can also take the form of an interjection or repetition used for clarification. Furthermore, the switch underlines the speaker's personal involvement and desire to be well understood (Hoffman, 1991).

\section{Persuasion}

Trying to persuade an audience, people of bilingual communities may employ code switching. Rihane (2007) states that people of bilingual communities switch their language to attract attention and persuade an 
audience. Nerghes (2011) says that code switching draws the participant's attention and enhances their motivation to scrutinize the message presented. Rihane (2007) adds that switches make listeners realize that the speaker asks them to pay attention to the speaker. As a result, the switches increase the success of reaching the goal of persuading the audience. In addition, Nerghes states that code switching is an effective strategy that leads to systematic processing of information especially when associated with strong arguments (Nerghes, 2011).

\section{Solidarity}

Holmes (1992) states that different kinds of relationships are often expressed through different codes. Thus, code switching can arise from individual choice or become a major identity marker for a group of speakers who must deal with more than one language in their lives (Wardhaugh, 2006, p. 101). Hence, people tend to use code switching in a bilingual community to show solidarity. Rihane (2007) states, "Code switching can be used to express solidarity between people from different or the same ethnic groups (p.5)." Gal (1988, p. 247 as cited in Wardhaugh 2006) adds that code switching is a conversational strategy used to establish, cross or destroy group boundaries; to create, evoke or change interpersonal relations with their rights and obligations.

\section{Affection}

Code switching can also express personal feeling. Speakers switch codes to express happiness, excitement, anger, sadness, and many other feelings (Rihane, 2007). Moreover, the code switching does not always convey referential content but also affection content (Holmes, 1992).

\section{The Use of Code Switching as the Classroom Language}

Mattson and Burenhult (1999) state that code switching has three functions in language learning classroom which are as a topic switch, affective functions, and repetitive functions. First, code switching as the topic switch. Sert (2005) states that the teachers alter their languages according to the topic that is under discussion. Sert (2005) adds that code switching serves as a bridge from native languages to new foreign languages content that is constructed in order to transfer the new content and meaning. Likewise, Cole (1998) states, "A teacher can exploit students' previous L1 learning experience to increase their understanding of L2" (as cited in Sert, 2005, p.3). Second, code switching also carries affective functions that serve for expression of emotions (Sert, 2005). Sert (2005) says that teachers use code switching in order to build solidarity and intimate relations with the students. A study by Ahmad in 2009 shows that code switching used in the class 
can function as affective aspect helps learners to enjoy their learning due to their ability to comprehend the teachers' input. The comprehensible input also allowed them to feel less stressful and to become more comfortable to learn. Once the students are comfortable with the environment, without any unnecessary anxiety, the learners are able to focus and participate in classroom practice and activities more successfully (Ahmad, 2009). Third, code switching has a repetitive function. In this case, the teachers use code switching in order to transfer the necessary knowledge for the students for clarity (Sert, 2005). Sert adds that the teachers deliver the instruction in the target language, and then switch to native language in order to clarify meaning. The teachers employ code switching to stress importance on the foreign language content for efficient comprehension.

\section{Methodology}

This study employed a qualitative approach specifically basic interpretative study to understand the experience of the research participants who employed code switching in their instructional languages (Ary, Jacobs, Sorensen \& Razavieh, 2010, p. 29). The writer chose six out of twenty lecturers who taught in the third semester classes based on some informal interviews with some third semester students. The participants' names were symbolized with P1-P6. Further, the writer became the main instrument in collecting and analyzing data by employing an interview guideline. The data of this study were analyzed employing Creswell's (2009) qualitative data analysis procedure as the basic technique of the data analysis.

\section{Findings and Discussion}

Types of Code Switching Employed by Participants in Their Instructional Languages

There were two types of code switching employed by the six research participants, namely, situational and metaphorical code switching. Each will be described in the following parts.

\section{Situational Code Switching}

The situational code switching appeared when one language is used in one situation and another language is used in a different situation (Wardhaugh, 2006). The writer discovered that all participants employed situational code switching in their instructional languages in their classes. They employed situational code switching which defined as code switching occurred when situations, particularly addressees, settings and activity types change speakers' language choices (Blom \& Gumperz, 1972). One of the considerations for employing this situational code switching was the addressees as exemplified in the following examples in table 1 . 
Table 1 The Addressees as Participants' Consideration for Code-switching

\begin{tabular}{|l|}
\hline \multicolumn{1}{|c|}{ Utterances } \\
\hline $\begin{array}{l}\text { "I use code switching depends(depending) on the type of } \\
\text { class and whether I need to use it or not (P1)." }\end{array}$ \\
\hline "If I mainly use English, maybe some students will have \\
some problems in understanding. So, code switching is for \\
lessening the tension and helping students to understand \\
better (P2).". \\
\hline
\end{tabular}

The utterances in table 1 show that the participants employed situational code switching considering their students' language mastery (Nishimura, 1997). The writer could also deduce that the participants code-switched in the situation when students seemed to not understand the participants' explanation. The participants wanted the message delivered well to students by employing situational code switching, in this case, Indonesian language, that students understood better. In addition, the participants realized that the L1 should be employed in the form of situational code switching in order to make their students understand. Specifically, P2 said that if she mainly used English, maybe some students would have some problems in understanding. P2's statement shows that she considered the need to switch to the language that understandable for her students.

\section{Metaphorical Code Switching} In metaphorical code switching the language switch relates to particular kinds of topic or subjects matter rather than to change in social situation (Wardhaugh, 2006). The alternation enriched a situation and it allowed for an allusion to more than one social relationship within the situation as the participants wanted to achieve special communication effects. Moreover, the language switch related to particular kinds of topics or subject matter rather than to change the social situation (Blom and Gumperz, 1972). The interview results proved that the participants also employed metaphorical code switching as their instructional language. The participants tried to enrich the situations they were discussing. The utterances that show how the participants employed code switching for enriching the situation can be seen in the table below: 
Table 2 Code Switching Employed to Enrich the Situations

\begin{tabular}{|l|}
\hline \multicolumn{2}{|c|}{ Utterances } \\
\hline "Mudeng atau Mubeng? (P2)" \\
"Do you know in Flores? Di Flores kalau orang yang \\
ngomong terus dan gak mau bicara (maybe he means \\
"bekerja") namanya itu dia bagaikan apa? Pantat ayam. \\
Tau Pantat ayam? (P3)" \\
\hline
\end{tabular}

In the table above, P2 directly said, "Mudeng atau mubeng?" after her explanation in her structure class. It can be inferred that $\mathrm{P} 2$ employed two languages that were Indonesian and Javanese languages. The participant employed code that enriched the situation in the form of "mudeng (understood)" understood" and "mubeng (goes around)". The use of mudeng and mubeng enriched the situation in the way that the code was understood by both the participant and her students. The code also made the students realized that the participant asked for their confirmation. The same situation also happened when P3 employed code switching when the students were too noisy, and then he warned the students by saying "pantat ayam". Pantat ayam is a metaphorical term that meant someone who only talked without doing something. It related to the situation when the students were noisy and they did not do their task. The use of the code as a metaphor brought a special communication effect that well understood by both addresser and addressee.
The Reasons for Participants Employing Code Switching in Their Instructional Language

The section discussed the findings to answer the second research problem that was the reasons for ELESP participants to employ switching their instructional language.

\section{Topic}

Talking about a particular topic could cause a switch, either because of lack of facility in the relevant register or because certain items trigger off various connotations which are linked to experiences in a particular language (Hofffman, 1991). This situation occurred to all participants. The interview results show that some participants code switched since they realized that some words in the Indonesian language did not have relevant words in English. The examples can be seen in table 3. 
Table 3 Code Switching Emerged as there was no Relevant Word in English

\begin{tabular}{|l|}
\hline \multicolumn{1}{|c|}{ Utterances } \\
\hline "I will use the original word if there are no correspondence words \\
when I talk about some topic so there will be no shifted meaning \\
(P2)." \\
"I will use Indonesia (when I am talking about some words that do \\
not have words for the same sense in English), like what I have said \\
before like alay, baper, and some example from Twitter. I use the \\
example from Twitter and it is in Indonesia. I ask them to analyze it \\
(P4)."
\end{tabular}

From the P2 and P4's statements, the writer could infer that the participant code-switched some words to Indonesian due to the lack of expressions in English. The expression could be translated but the sense was different. Further, P4 did not translate the word alay and baper since those words were actually language phenomena created by teens in Indonesia. P4 realized it and she employed those words as the materials for students to analyze since the root words from those languages were from the Indonesian language.

In addition, the results of the interview show that participants code-switched on some topics to make their students get a better understanding on the topic the were talking about. The participants believed that by code-switching their students would get the idea of the topic easier. The utterances that show the participants code-switched on some topics for students' better understanding could be seen in table 4.6.

Table 4 Code Switching on Some Topics for Students' Better Understanding

\begin{tabular}{l} 
Utterances \\
\hline "I realize in some subjects, the concept will be easier to \\
retrieve by students if the concept is communicated using \\
English and local languages(P2)." \\
"(I switch to the Indonesian language) Usually, when I explain \\
(a) very complex issue or topic, and the idea is very \\
complicated, sometimes you need to translate the idea into \\
English, sometimes not always(P3)."
\end{tabular}


The writer could infer, from the results on table 4 , that while talking about some topic, the participants considered employing the code switching to help them communicate the idea better. Further, the switches were also believed by the participants could help students to understand what the participant said. In this case, code switching served as a bridge from the native language to new foreign language contents that were constructed in order to transfer the new contents and meanings (Sert, 2005). These switches were triggered when participants were discussing a complex topic that makes students hard to understand.

\section{Addressee}

The participants also codeswitched according to addressees they are talking. This code switching depended on addressees' background, relation to the speaker, and language mastery. The interview results indicated that participants mostly considered their students' language mastery as their reason to code-switch. The following table presents the examples of utterances by the participants in employing code switching to accommodate their students' comprehension.

Table 5 Code Switching Employed to Accommodate Students' Comprehension

\begin{tabular}{|l|}
\hline Utterances \\
\hline "I use code switching depends on the type of class and whether \\
I need to use it or not(P1)." \\
"English is not the students' first language, so we have to \\
consider the limitation of students. We cannot insist students to \\
catch up with full English learning. Moreover, the use of code \\
switching is in phase(P2)." \\
"The code switching that I use depends on the students I am \\
communicating with(P3)." \\
\hline
\end{tabular}

Those examples show that the participants did consider about their students' language mastery. It can be inferred that the participants did not force themselves to use English in the class. The writer concluded that the participants' consideration was the fact that the participants knew the English of some students had not been good yet. Moreover, the writer inferred that the participant felt that forcing students was not good for both of them so the participant employed code switching in his instructional language to help students understand. 


\section{Emphasis}

The interview results show that being emphatic about something was a consideration for the participants to switch their language. Speakers switched their language in order to make students understand what they were emphasizing about and underline the speakers' involvement. The switch could be in the form of interjection or repetition (Hoffman, 1991). The statements on table 6 show how the participants emphasize about some important message employing code switching.

Table 6 Code Employed to Emphasize Participants' Messages

\begin{tabular}{|l|}
\hline Utterances \\
\hline "I use code switching in order to convey messages that students \\
have to understand (P1)." \\
"I want to get my idea across; I want to communicate my ideas \\
with my students (using the Indonesian language)(P3)." \\
"(I spoke bahasa Indonesia) For clarification and for change \\
because we need a chance(P5)."
\end{tabular}

The examples illustrated in table 6 show that most all of the participants employed code switching because they wanted to emphasize some important things. In this case, the participants wanted to make the students understand the important contents they explained. The examples show clearly that the participants considered the need of clarification for their explanation. Therefore, the participants repeated the explanation employing code switching. The participants understood that the most important thing was conveying the message that their students had to understand. The repetition that employed code switching was useful for students' understanding. In this case, the participants employed code switching in order to deliver the necessary knowledge for the students for clarity (Sert, 2005).

\section{Persuasion}

The participants also employed the code switching to get students' attention. According to Nerghes (2011), code switching will draw the participant's attention and will enhance their motivation to scrutinize the message presented. Moreover, Nerghes adds code switching leads to systematic processing of information especially when associated with strong arguments. Rihane (2007) argues that switches make listeners realize that the speaker asks them to pay attention to the speaker. After interviewing the participants, the writer found that the participants realized that the use of code 
switching make their students pay attention to them and make their message understood better. These are examples show how the participants employed code switching for persuading their students:

Table 7 Code Switching Employed to Persuade The Students

\begin{tabular}{|l|}
\hline Utterances \\
\hline "Berteman dengan kerbau lumpuh pasti akan ikut lumpuh. \\
... So, what does it mean? "You have to be careful in \\
picking up friends (P3)." \\
"Tapi, bagaikan tikus mati di lumbung beras, what does it \\
mean? Anda kuliah di Sanata Dharma, one of the best. You \\
have good lectures, good facilities, semuanya hebat. The \\
Internet, everything. Books, library, one of the best, \\
mungkin not the best in Indonesia. Anda ini beruntung, tapi \\
Karena Anda tidak tahu, Anda bisa mati seperti tikus.(you \\
are lucky, but if you do not know, you will die like a mouse) \\
(P3)"
\end{tabular}

Observing the participants' statements above, the writer concludes that participants employed code switching to persuade the students to understand and/or do something related to the participants' messages. In this study, the writer concerned on the way the participants code-switched to persuade their students to scrutinize the message given with the strong arguments. P3 emphasized live lesson his students should pay attention by employing code switching. Moreover, P3 inquired his students being careful in picking friends since friends would affect them so much. He also asked his students to pay attention to the results of not utilizing the facility they have: students might die like a mouse in the barn full of rice.

\section{Solidarity}

The interview results revealed that the participants also employed code switching for showing their solidarity with their students. Code switching could arise from individual's choice or become a major identity marker for a group of speakers who must deal with more than one language in their lives (Wardhaugh, 2006, p. 101). Further, the participants employed the Indonesian language to show their solidarity as Indonesian. 
Table 8 Code Switching Employed to Express Solidarity

\begin{tabular}{|l|}
\hline Utterances \\
\hline "I think students if I say in Indonesia (Indonesian \\
language), the students will feel like I am one of them. But \\
If I say in English, I am just an English teacher. If I say in \\
Bahasa (Indonesian language), they will feel like I am also a \\
learner of English sharing my experience as an Indonesian \\
learning English. Because teaching is not a matter of \\
transferring knowledge but building a good relationship with \\
students, trust, also help students to have confidence (P3)." \\
\hline
\end{tabular}

The examples on table 8 illustrate how participants show their solidarity with their students. P3 showed clearly his intention of employing code switching. He wanted to be the part of the students' community. P3 even tried to make his students trust him. From those cases, the writer could conclude that the participants employed code switching to show their solidarity. By establishing a closer relationship with the students, the participants were able to create a better atmosphere for free discussions that will help students to focus and participate in classroom practice and activities successfully.

\section{Affection}

The participants also showed their affection employing the Indonesian language. Rihane (2007) says that speakers use code switching to express certain feelings and attitudes. The expression of showing affection was usually shown to express the participants feeling responding to their students' attitude. The examples of the participants' utterance to express their feeling can be seen below.

Table 9 Code Switching Employed to Express Participants' Feelings

\begin{tabular}{|c|}
\hline Utterances \\
\hline "Kalau kalian gak bertanya berarti paham. (if you did \\
not ask, it means you understood) (P2)" \\
\hline "Terus gimana caranya kalau seperti ini untuk \\
membantu kalian kalau kalian gak ngomong kan saya \\
gak tau kalau kalian bermasalah tapi kamu sendiri gak \\
membantu dirimu kalau kamu gak menyampaikannya \\
(then, how would I help you if you do not tell me. I do \\
\hline
\end{tabular}


not know if you have problem and you do not help yourself when you do not tell me.) (P2)?”

The data above show that the participants also employed code switching for expressing the participants' feeling. P2 showed her frustration in the Indonesian language when her students were afraid to ask her. She found that some of her students did not understand after she explained theories in Structure III. So, she employed code switching to express her feeling and encourage the students not to be afraid to ask.

\section{Other Findings}

After analyzing the data from the interview results, the writer found two other findings related to the reason for code switching which was not listed in the Hoffman (1991), Holmes (1992), and Wardhaugh's (2006) list of the reasons for code-switching. The reasons are the nature of the subject and code switching as the strategy for teaching.

\section{The Nature of the Subject} After interviewing the participants, the writer found that the subject the participants taught also influenced the consideration of the participants to code-switch. The utterances on table 10 show how the nature of the subject influenced the participants to code-switch.

Table 10 The Nature of the Subject

\begin{tabular}{|l|}
\hline Utterances \\
\hline "So, it depends also on the nature (of the subject), on \\
the subject, method, and what you teach. So, you need \\
to reflect. Particularly, sometimes it is not easy for us \\
to speak in English explain a difficult concept. The \\
word is too difficult for students. You need to \\
paraphrase. Again, it depends on the nature of the \\
subject, on the purpose of teaching: what you want \\
your students to learn? (P3)" \\
"Switch code only used in teaching English when it is \\
helpful for them to understand the subject matter. \\
Because, English, when I teach content courses, it is \\
only means of communication. My theory is switch \\
code is only used on the emergency situation. So, I do \\
code switch if it is beneficial to students, not me (P6)." \\
\hline
\end{tabular}


From the utterances on table 10, the writer could infer that most of the participants consider employing code switching for some subject. The writer found that on some content subject the participants code-switch to explain or re-explain some materials. The participants felt that the most important thing was the message that should be delivered well to students.

\section{Strategy}

The interview results also reveal that the participants employ code switching as their strategy in the class. Table 11 shows the participants' utterances showing the use of code switching as their strategy.

Table 11 Code Switching as the Participants' Strategy

\begin{tabular}{|l|}
\hline Utterances \\
\hline "The use of code switching is in phase (P2)." \\
"You code switch because you want to save the time. \\
You don't want to explain everything in English. One \\
idea (is) in English and it takes a long time to explain \\
while you can easily explain in Bahasa. It is easier (P3)." \\
"In fact, code switch is a strategy. (it is) Not, because of \\
my problem of using the language. It is only one of the \\
tools to help students understand (P6)."
\end{tabular}

From the data in table 4.19, the writer could infer that the participants employed code switching as their strategy. P2 indicated that she employed code switching in a phase. It meant that she did not directly employ code switching all the time. Further, P6 believed that code switching could be a tool to help students understand.

\section{Conclusion}

The data showed that both situational and metaphorical code switching were employed by the participants. However, the participants mostly employed situational code switching to help their students understand better. Moreover, there were eight reasons for the participants to code-switch. They were topic, addressee, emphasis, persuasion, solidarity, affection, the nature of the subject and as the participants' strategy. It showed that the participants did consider their use of code switching. It was not because the participants were lack of English mastery but as the tool to help students understand better 


\section{References}

Ahmad, B.H. (2009). Teachers' code-switching in classroom instructions for low English proficient learners. The CCSE Internet Journal.

Adegbite, F., \& Akindele, W. (1999). The sociology and politics of English in Nigeria: An introduction. Retrieved May 28, 2015, from http://www.getitwriteonline.com/archive/020204whencommabfand.htm.

Ary, D., Jacobs, L.C., Sorensen, C., \& Razavieh, A. (2010). An introduction to research in education. Belmont: Wadsworth.

Blom, J.-P., \& Gumperz, J. J. (1972). Social meaning in linguistic structures: codeswitching in Norway. In John J. Gumperz, Dell Hymes (eds.) Directions in sociolinguistics: The ethnography

communication. New York: Holt, Rinehart and Winston Inc.

Creswell, J. (2009). Research design: Qualitative, quantitative and mixed methods approaches. Los Angeles: SAGE Publications Inc.

Gal, S. (1988). The political economy of code choice. In M. Heller,(ed.), Codeswitching: Anthropological and sociolinguistic perspectives, 48, 245-64.

Harmer, J. (2007). The practice of English language teaching. Cambridge: Longman.

Hoffman, C. (1991). An introduction to bilingualism. London: Longman.

Holmes, J. (1992). An introduction to sociolinguistics. London: Longman.

Modupeola, O. R. (2013). Code-Switching as a teaching strategy: Implication for English Language teaching and learning in a multilingual society. IOSR Journal of Humanities and Social Science, 14(3), 92-94.

Nishimura, M. (1997). Japanese/English code-switching. New York: Peter Lang.

Radford, A., Atkinson, M., Britain, D., Clahsen, H., \& Spencer, A. (1999). Linguistics: An introduction. Cambridge: Cambridge University Press.

Rihane, W. M. (2007). Why do people code-switch: A sociolinguistic approach. Retrieved May 28, 2015, from www.academia.edu/2649532/Why_do_People_CodeSwitch_A_Sociolinguisti c_Approach.

Sert, O. (2005). The Functions of Code-Switching in ELT Classrooms. Online Submission, 11(8). Retrieved May 28, 2015, from https://jyx.jyu.fi/dspace/bitstream/handle/123456789/7407/G0000707.pdf.

Wardaugh, R. (2006). An introduction to sociolinguistics. West Sussex: WileyBlackwell. 